\title{
Folate Distribution in Cultured Human Cells
}

\author{
STUDIES ON 5,10- $\mathrm{CH}_{2}-\mathrm{H}_{4}$ PTEGLU REDUCTASE DEFICIENCY
}

\author{
David S. Rosenblatt, Bernard A. Cooper, and Sally Lue-Shing, \\ MRC Genetics Group and Department of Pediatrics; Haematology Division, \\ Royal Victoria Hospital, and Department of Physiology, McGill University, \\ Montreal, Quebec H3H 1 P3 \\ Paul W. K. Wong, Section of Genetics, Department of Pediatrics, Presbyterian- \\ St. Luke's Medical Center, Rush Medical School, Chicago, Illinois 60612 \\ STANLEY BERLOW, Department of Pediatrics, Waisman Center on Mental Retardation \\ and Human Development, University of Wisconsin, Madison, Wisconsin 53706 \\ Kuniaka Narisawa, Department of Pediatrics, Tohoku University, School of \\ Medicine, Sendai, Japan \\ Regula Baumgartner, Metabolic Unit, Basler Kinderspital, Basel, Switzerland
}

\begin{abstract}
A B S TRACT We have studied the distribution of folate coenzyme forms in cultured human fibroblasts from control lines and from lines derived from nine patients representing all of the published reports of $5,10-\mathrm{CH}_{2}-\mathrm{H}_{4}$ PteGlu reductase deficiency. Based on mobility on DEAE-Sephadex and differential microbiological assay the major folate fractions in extracts of human fibroblasts were $5-\mathrm{CH}_{3}-\mathrm{H}_{4} \mathrm{PteGlu}, 10-\mathrm{CHO}$ $\mathrm{H}_{4} \mathrm{PteGlu}$, and 5-CHO- $\mathrm{H}_{4} \mathrm{PteGlu}$ with smaller fractions, which included 5- $\mathrm{CH}_{3}-\mathrm{H}_{2} \mathrm{PteGlu}$, 10-CHO-PteGlu, and $\mathrm{H}_{4} \mathrm{PteGlu}$. Evidence that the $5-\mathrm{CHO}-\mathrm{H}_{4} \mathrm{PteGlu}$ may have been derived from $5,10-\mathrm{CH}=\mathrm{H}_{4}$ PteGlu during extraction is presented. In most of the mutant fibroblasts the absolute concentration of $5-\mathrm{CH}_{3}-\mathrm{H}_{4} \mathrm{PteGlu}$ was lower than in control cells but the proportion of intracellular folate which was $5-\mathrm{CH}_{3}-\mathrm{H}_{4}$ PteGlu was strikingly lower in mutant cells when determined by chromatography or differential microbiological assay. In both control and mutant cells most of the $5-\mathrm{CH}_{3}-\mathrm{H}_{4}$ PteGlu was polyglutamate. The proportion of intracellular folate which was polyglutamate was similar in control and mutant cells. A direct relationship was ob-
\end{abstract}

This work was presented in part at the 564th meeting of the Biochemical Society, Trinity College, Dublin, Ireland, Sept. 1976 (Biochem. Soc. Trans. 4: 921-922).

This investigation was supported by grants from the Medical Research Council of Canada MT802 to Dr. Cooper and by a Medical Research Council Genetics Group Grant to Dr. Rosenblatt. Dr. Cooper is a Medical Research Associate of the Medical Research Council of Canada.

Received for publication 14 August 1978 and in revised form 18 December 1978. served between the proportion of cellular folate which was $5-\mathrm{CH}_{3}-\mathrm{H}_{4}$ PteGlu, and both the clinical severity of this disorder and the residual enzyme activity indicating that the distribution of different folates may be an important control of intracellular folate metabolism. These studies indicate that $5,10-\mathrm{CH}_{2}-\mathrm{H}_{4} \mathrm{PteGlu}$ reductase is the only significant intracellular pathway for the generation of $5-\mathrm{CH}_{3}-\mathrm{H}_{4} \mathrm{PteGlu}$, that the activity of this enzyme regulates the level of this folate in control and mutant cells under conditions of culture used here, that the majority of intracellular folate is in the polyglutamate form, and that the relative distribution of folates may control folate metabolism by interaction in the various folate reactions.

\section{INTRODUCTION}

Deficiency of 5,10- $\mathrm{CH}_{2}-\mathrm{H}_{4} \mathrm{PteGlu}$ reductase, (EC.1.1.1.68) an autosomal recessive inborn error of folate metabolism, is characterized by moderate degrees of homocystinemia and homocystinuria accompanied by normal or low plasma methionine levels. The clinical findings in the twelve patients described to date (1-8) has ranged from seizures, apnea, coma, and death in infancy (4) to mild mental retardation and neurological impairment in adolescence (5). The deficiency of 5,10$\mathrm{CH}_{2}-\mathrm{H}_{4}$ PteGlu reductase was first described in fibroblasts $(3,5,9)$ but has now been confirmed in liver $(4,6)$, kidney (4), brain (4), and leukocytes $(3,4)$. Preliminary studies showed a decreased ratio of $5-\mathrm{CH}_{3}-\mathrm{H}_{4} \mathrm{PteGlu}$ to total folates in the fibroblasts of several deficient patients (10) and an absence of $5-\mathrm{CH}_{3}-\mathrm{H}_{4}$ PteGlu in the 
serum and erythrocytes of one patient (4) has been described.

This study describes the distribution of folate monoglutamates and folate polyglutamates and the composition of each in fibroblasts from nine patients representing all of the published reports of $5,10-\mathrm{CH}_{2}-\mathrm{H}_{4} \mathrm{PteGlu}$ reductase deficiency.

\section{METHODS}

Materials. Tissue culture medium was purchased from Grand Island Biological Co. (Grand Island, N. Y.). Fetal calf serum was purchased from Flow Laboratories, Inc. (Rockville, Md.). All other chemicals were of reagent grade and obtained commercially.

Cell culture. Fibroblasts were obtained from nine patients representing all known publications of $5,10-\mathrm{CH}_{2}-\mathrm{H}_{4}$ PteGlu reductase deficiency (Table I) and from controls.

On arrival in our laboratory all lines were routinely tested for mycoplasma contamination (11). Four such lines $(549,550$, 583 , and 654 ) were found to be contaminated with mycoplasma. Because the patients had either died or were not available, repeat biopsy was not possible. These contaminated cells were grown in a separate laboratory. No difference in the parameters involved in these studies could be found between the five mycoplasma-free and the four mycoplasma-contaminated cells except that insufficient mycoplasma-contaminated cells could be obtained for all studies. All cells were grown to confluence in roller bottles (Bellco Glass Inc., Vineland, N. J.) of $690 \mathrm{~cm}^{2}$ surface area containing $100 \mathrm{ml}$ medium in an atmosphere of $5 \% \mathrm{CO}_{2}$ and $95 \%$ air. The standard medium consisted of Eagle's minimum essential medium, which contains PteGlu $2.3 \mu \mathrm{M}(1 \mathrm{mg} /$ liter $)$ plus nonessential amino acids. All media contained $10 \%$ fetal calf serum dialyzed where indicated against a 10 -fold vol of $0.9 \% \mathrm{NaCl}$ with two changes. Cells were released from the surface of the roller bottles by exposure to $0.25 \%$ trypsin for $10 \mathrm{~min}$ at $37^{\circ} \mathrm{C}$. The cells were resuspended in Dulbecco's phosphate-buffered saline solution $(\mathrm{pH}$ 7.4), and an aliquot was removed for enumeration in a Coulter

TABLE I

Features of 5,10-CH${ }_{2}-\mathrm{H}_{4}$ PteGlu Reductase Deficient Cell Lines

\begin{tabular}{|c|c|c|c|c|c|c|}
\hline $\begin{array}{c}\text { Patient } \\
\text { and line } \\
\text { designation }\end{array}$ & $\begin{array}{l}\text { Rank of clinical } \\
\text { severity* }\end{array}$ & Sex & Age & $\begin{array}{l}\text { Cell type in } \\
\text { literature }\end{array}$ & $\begin{array}{c}\mathrm{CH}_{2}-\mathrm{H}_{4} \text { PteGlu } \\
\text { reductase } \\
\text { activity } 1\end{array}$ & $\begin{array}{c}\text { Reference } \\
\text { No. }\end{array}$ \\
\hline \multicolumn{7}{|c|}{$y r$} \\
\hline CP (488) & 1 & M & 16 & Fibroblasts & $\begin{array}{l}1.39 \\
1.7\end{array}$ & $\begin{array}{l}5 \\
9\end{array}$ \\
\hline LM (451) & 3 & $\mathrm{~F}$ & 15 & Fibroblasts & $\begin{array}{l}0.77 \\
1.6\end{array}$ & $\begin{array}{l}5 \\
9\end{array}$ \\
\hline $\mathrm{BM}(452)$ & 3 & $\mathrm{~F}$ & 17 & Fibroblasts & $\begin{array}{l}0.82 \\
1.2\end{array}$ & $\begin{array}{l}5 \\
9\end{array}$ \\
\hline WM (548) & 3 & M & 11 & Fibroblasts & 1.1 & 1 \\
\hline TC (549) & $51 / 2$ & $\mathrm{~F}$ & 9 & Fibroblasts & 0.53 & 2 \\
\hline $\operatorname{MEC}(550)$ & $51 / 2$ & $F$ & 7 & Fibroblasts & $\begin{array}{l}0.97 \\
1.3\end{array}$ & $\frac{2}{\S}$ \\
\hline GS (654) & $71 / 2$ & $\mathbf{M}$ & $24 / 12$ & Leukocytes & 0.94 & 3 \\
\hline GP (583) & $71 / 2$ & M & 2 & Fibroblasts & 0.16 & $"$ \\
\hline SS $(670)$ & 9 & $\mathrm{~F}$ & $5 / 12$ & $\begin{array}{l}\text { Leukocytes } \\
\text { Fibroblasts }\end{array}$ & $\begin{array}{l}0 \\
0.1\end{array}$ & $\begin{array}{l}4 \\
\S\end{array}$ \\
\hline \multicolumn{7}{|c|}{ Control } \\
\hline \multicolumn{2}{|c|}{ Reference } & \multicolumn{4}{|c|}{$5,10-\mathrm{CH}_{2}-\mathrm{H}_{4} \mathrm{PteGlu}$ reductase activity 1} & Cell type \\
\hline \multicolumn{3}{|c|}{ Rosenblatt and Erbe (9) } & \multicolumn{2}{|c|}{$8.6 \pm 1.4$} & \multicolumn{2}{|r|}{ Fibroblasts } \\
\hline \multicolumn{3}{|c|}{ Mudd et al. (5) } & \multicolumn{2}{|c|}{$5.04 \pm 1.36$} & \multicolumn{2}{|r|}{ Fibroblasts } \\
\hline \multicolumn{3}{|c|}{ Narisawa et al. (4) } & \multicolumn{2}{|c|}{$2.68 \pm 0.78$} & \multicolumn{2}{|r|}{ Leukocytes } \\
\hline \multicolumn{3}{|c|}{ Wong and Berlow (3) } & \multicolumn{2}{|c|}{$9.38 \pm 1.22$} & \multicolumn{2}{|r|}{ Leukocytes } \\
\hline \multicolumn{3}{|c|}{ Wong et al. (2) } & \multicolumn{2}{|c|}{7.88} & \multicolumn{2}{|r|}{ Fibroblasts } \\
\hline \multicolumn{2}{|c|}{ Baumgartner and Wongi } & & \multicolumn{2}{|r|}{4.72} & \multicolumn{2}{|r|}{ Fibroblasts } \\
\hline
\end{tabular}

* Least severe (1), most severe (9).

† Nanomoles of formaldehyde per milligrams protein per hour.

$\S$ Rosenblatt, D. S., and B. A. Cooper. Unpublished observation.

"Baumgartner, R., and P. W. K. Wong. Unpublished observations. 
counter (Coulter Electronics, Inc., Hialeah, Fla.). The cell pellet was washed twice in phosphate-buffered saline and collected by centrifugation (12). $5,10-\mathrm{CH}_{2}-\mathrm{H}_{4} \mathrm{PteGlu}$ reductase activity in cell extracts were measured as previously described (13).

Folate determinations. Folate was assayed microbiologically with Lactobacillus casei ATCC 7469, Pediococcus cerevisiae ATCC 8081, and Streptococcus fecalis ATCC 8083, using aseptic addition of samples to sterile medium already inoculated with assay organisms as described previously (14). This technique represented a slight variation of standard techniques. Because $S$. fecalis required a higher folate concentration than the other organisms for logarithmic growth, folate concentration in fibroblasts could not always be reliably determined with this organism.

For fractionation of folates on Sephadex G-25, washed fibroblasts were extracted in $0.05 \mathrm{M}$ sodium phosphate $\mathrm{pH} 9$ containing $8.5 \mathrm{mM}$ ascorbate, protein precipitated with heat, and the clear supernate obtained after centrifugation was analyzed. For assay of folate content by microbiological methods and by DEAE-Sephadex, fibroblasts were extracted in $0.1 \mathrm{M}$ sodium acetate $\mathrm{pH} 4.5$ containing $8.5 \mathrm{mM}$ ascorbate, and the extract was treated with $10 \%(\mathrm{vol} / \mathrm{vol})$ of folate-depleted normal human serum for $90 \mathrm{~min}$ at $37^{\circ} \mathrm{C}$ followed by heating and analysis of the supernate. The $\mathrm{pH}$ of the mixture of extract serum and buffer was 5.2-5.3.

Fractionation of folate on DEAE-Sephadex was as described previously $(15,16)$ using a linear gradient $(0.1-0.8 \mathrm{M})$ of potassium phosphate $\mathrm{pH} 6.1$. Folate polyglutamates were differentiated from short-chain folates in extracts untreated with conjugase by filtering through Sephadex G-25 as described previously (17). To allow assay of the relatively small amount of Pediococcus-active folate from specimens containing $10^{6}$ cells, filtration utilized a column of $0.9 \times 30 \mathrm{~cm}$, and $1-\mathrm{ml}$ fractions were collected.

Folate polyglutamates were deconjugated to monoglutamates with $10 \%$ folate-depleted serum within the assay tubes at $\mathrm{pH} 4.5$, after which the $\mathrm{pH}$ was adjusted to 6.9 and $0.8 \mathrm{ml}$ of each fraction was mixed with concentrated assay medium containing the assay organism, and incubated without precipitation of protein. Standards and controls were assayed in a similar fashion. These samples were assayed only with $L$. case $i$ and $P$. cerevisiae. This technique allowed assay of as little as $500 \mathrm{pg} / \mathrm{sample}$. When fibroblast folate excluded from the gel was refiltered, it was again excluded from the gel. When the extract was treated with conjugase before filtration, all the folate filtered within the included volume of the gel, indicating that the technique differentiated between polyglutamyl and short-chain folates.

For the microbiological assays, care was taken to ensure that the samples were diluted into the range where growth of the microorganism was directly proportional to the folate concentration (18). In all circumstances at least two dilutions within this assay range were achieved and concentrations calculated from these different dilutions were within $5 \%$ of each other.

Statistical analysis employed the Student $t$ test, using paired or unpaired observations, and the Mann-Whitney analysis for nonparametric statistics. When not otherwise qualified, $P$ values indicate the probability that values are different based on unpaired $t$ test analysis.

The distribution of folate forms at confluence was determined by chromatography of deconjugated extracts on DEAESephadex. Typical chromatograms of extracts of normal and mutant cells are shown in Fig. 1. Folate fractions eluted from the column were identified by comparison of the conductivity of the eluting buffer with that of standard folate coenzymes, including DL-10-CHO-H ${ }_{4}$ PteGlu, DL-10-CHO-PteGlu, DL-

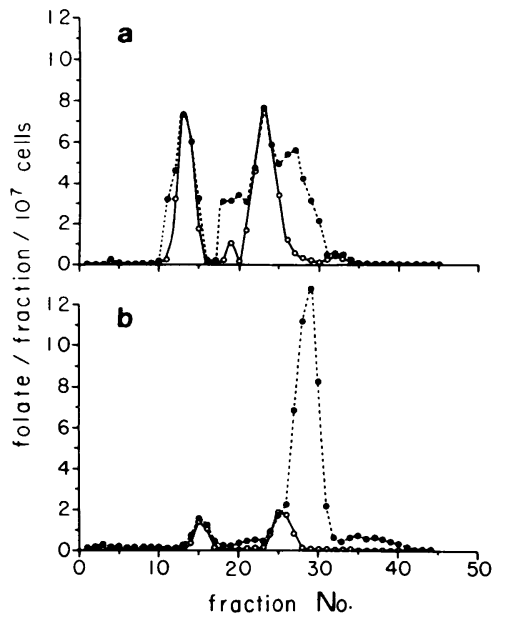

FIGURE 1 DEAE-Sephadex elution pattern of folate forms in a deconjugated extract of $5,10-\mathrm{CH}_{2}-\mathrm{H}_{4} \mathrm{PteGlu}$ reductase deficient fibroblast line $451(a)$ and a normal line (316) $(b) .7 .8$ $\times 10^{7}$ cells of line 451 , and $5.1 \times 10^{7}$ cells of line 316 were suspended in $12 \mathrm{ml}$ of $0.1 \mathrm{M}$ sodium acetate $\mathrm{pH} 4.5$ containing $8.5 \mathrm{mM}$ ascorbate and the extract was treated with $10 \%$ (vol/vol) of folate-depleted human serum for $90 \mathrm{~min}$ at $37^{\circ} \mathrm{C}$ followed by heating. The extract was then fractionated on DEAE-Sephadex using a linear gradient $(0.1-0.8 \mathrm{M})$ potassium phosphate $\mathrm{pH}$ 6.1. The folate forms were identified on the basis of mobility and support of growth of test organisms L. case $i(\bigcirc)$ and $P$. cerevisiae $(O)$. The ordinate indicates total folate in nanograms per $9-\mathrm{ml}$ fraction per $10^{7}$ cells.

$5,10-\mathrm{CH}=\mathrm{H}_{4}$ PteGlu, DL-5-CHO- ${ }_{4}$ PteGlu, DL-5-CH ${ }_{3}-\mathrm{H}_{4}$ PteGlu, and PteGlu, with data published previously and by their support of growth of the assay organisms $(15,16)$. Because of the known lability of $5,10-\mathrm{CH}=\mathrm{H}_{4} \mathrm{PteGlu}$ and $5,10-\mathrm{CH}_{2}-$ $\mathrm{H}_{4}$ PteGlu under the conditions of extraction of the cells (19), these folates would not have been found in these cell extracts; the former would have been converted to a mixture of 10$\mathrm{CHO}-\mathrm{H}_{4}$ PteGlu and $5-\mathrm{CHO}-\mathrm{H}_{4} \mathrm{PteGlu}$, and the latter to $\mathrm{H}_{4} \mathrm{PteGlu}$. The folates eluting from the column were therefore identified as: fraction I, $10-\mathrm{CHO}-\mathrm{H}_{4} \mathrm{PteGlu}$; fraction II, 10CHO-PteGlu and 5- $\mathrm{CH}_{3}-\mathrm{H}_{2} \mathrm{PteGlu}$; fraction III, 5-CHO- $\mathrm{H}_{4}-$ PteGlu; fraction IV, 5- $\mathrm{CH}_{3}-\mathrm{H}_{4}$ PteGlu; and fraction $\mathrm{V}$, $\mathrm{H}_{4}$ PteGlu. Note that the folates in fraction II are oxidation products of those in fractions I and IV, and always represented a minority of folates eluting from the columns. Fractions II and $V$ were small and may also have contained traces of other folates.

\section{RESULTS}

The distribution of folate coenzyme forms determined from DEAE-Sephadex chromatography of extracts of control cell lines and of eight of the nine mutant cells is summarized in Table II. In six of the eight mutant lines analyzed by this method, the absolute concentration of 5- $\mathrm{CH}_{3}-\mathrm{H}_{4} \mathrm{PteGlu}$ (fraction IV) was lower than in the control lines, but the groups were not statistically different $(P=0.31$ [Student]; $P=0.30$ [Mann-Whitney]). The concentration of total folate coenzymes and of other folate fractions was also not different in normal 
TABLE II

Distribution of Folate Coenzyme Forms in Fibroblasts-DEAE-Sephadex

\begin{tabular}{|c|c|c|c|c|c|c|}
\hline & \multicolumn{6}{|c|}{ Fraction number } \\
\hline & I & II & III & IV & v & Total \\
\hline & \multicolumn{6}{|c|}{$n g$ folate $10^{6}$ cells } \\
\hline \multicolumn{7}{|l|}{$\begin{array}{l}\text { Control } \\
\text { lines }\end{array}$} \\
\hline 33 & 0.44 & 0.09 & 0.36 & 3.09 & 0.18 & 4.16 \\
\hline 316 & 0.46 & 0.14 & 1.09 & 4.33 & 0.30 & 6.32 \\
\hline Mean & 0.45 & 0.115 & 0.725 & 3.71 & 0.24 & 5.24 \\
\hline \multicolumn{7}{|l|}{$\begin{array}{l}\text { Mutant } \\
\text { lines }\end{array}$} \\
\hline 451 & 2.02 & 0.19 & 2.37 & 2.10 & 0.20 & 6.88 \\
\hline 452 & 0.63 & 0.19 & 0.8 & 1.53 & 0.24 & 3.40 \\
\hline 488 & 0.52 & 0.27 & 2.32 & 9.42 & 0.74 & 13.29 \\
\hline 548 & 2.00 & 0.92 & 2.32 & 4.66 & 0.77 & 10.68 \\
\hline 549 & 0.86 & 0.36 & 0.35 & 0.43 & 0.24 & 2.24 \\
\hline 550 & 1.21 & 0.24 & 0.59 & 1.25 & 1.25 & 4.55 \\
\hline 583 & 3.69 & 1.59 & 1.96 & 0.76 & 0.31 & 8.32 \\
\hline 670 & 1.50 & 0.5 & 0.86 & 0.04 & 0.22 & 3.29 \\
\hline Mean & 1.55 & 0.53 & 1.45 & 2.52 & 0.496 & 6.58 \\
\hline
\end{tabular}

Fibroblast extracts were fractionated on DEAE-Sephadex as described in Methods. The presumed identity of the folate fractions eluted sequentially: I, 10-CHO- ${ }_{4} \mathrm{PteGlu}$; II, 10-CHO-PteGlu and 5- $\mathrm{CH}_{3}-\mathrm{H}_{2}$ PteGlu; III, 5-CHO- $\mathrm{H}_{4}$ PteGlu; 'V, 5- $\mathrm{CH}_{3}-\mathrm{H}_{4}$ PteGlu; V, $\mathrm{H}_{4}$ PteGlu.

and mutant cells $(P=0.30-0.40$ by Student $t$ and Mann-Whitney test).

The concentration of $5-\mathrm{CH}_{3}-\mathrm{H}_{4} \mathrm{PteGlu}$ and of total folates in the cells was also measured by comparing the folate activity in cell extracts for $L$. casei and for $P$. cerevisiae. These data are summarized in Table III. By this method most mutant cells were found to have a lower concentration of $5-\mathrm{CH}_{3}-\mathrm{H}_{4} \mathrm{PteGlu}$ than did normal cells $(P=0.017)$ although again this was not invariably true. Based both on column chromatography (Table II) and direct assay of extracts (Table III) the proportion of intracellular folate which was $5-\mathrm{CH}_{3}-\mathrm{H}_{4}$ PteGlu was significantly lower in mutant cells $(P$ $=0.019$ and 0.0004 , respectively) and the proportion of fractions I and II are possibly higher in mutant cells $(P=0.09$ and 0.14 Student; $P=0.04$ and 0.04 Mann-Whitney).

The proportion of intracellular folate which was 5- $\mathrm{CH}_{3}-\mathrm{H}_{4}$ PteGlu determined by differential microbiological assay alone correlates well with that calculated from column chromatography $(r=0.90, P=0.0008$ [Student]), but the results from the former were consistently higher than from those from the column (leastsquares analysis of the data in Tables II and III revealed that $y=0.219+0.846 x$, where $y$ is the proportion of intracellular $5-\mathrm{CH}_{3}-\mathrm{H}_{4}$ PteGlu determined by
TABLE III

Folate Content of Fibroblasts by Differential Microbiological Determination

\begin{tabular}{|c|c|c|c|c|}
\hline & L. Casei & $\begin{array}{l}\text { P. Cere- } \\
\text { visiae }\end{array}$ & $5-\mathrm{CH}_{3}-\mathrm{H}$ & I,PteGlu \\
\hline & ng folat & $0^{6}$ cells & ng/106 cells & $\begin{array}{l}\text { fraction of } \\
\text { total folate }\end{array}$ \\
\hline \multicolumn{5}{|c|}{$\begin{array}{l}\text { Control cells } \\
\qquad(n=10)\end{array}$} \\
\hline Mean & 3.31 & 0.56 & 2.75 & 0.83 \\
\hline $\mathrm{SD}$ & 1.57 & 0.51 & 1.26 & 0.10 \\
\hline \multicolumn{5}{|c|}{ Mutant cells } \\
\hline 451 & 2.29 & 1.13 & 1.17 & 0.51 \\
\hline 452 & 2.90 & 1.28 & 1.62 & 0.56 \\
\hline 488 & 3.72 & 0.60 & 3.12 & 0.84 \\
\hline 548 & 4.05 & 1.61 & 2.44 & 0.60 \\
\hline 549 & 1.89 & 0.80 & 1.09 & 0.57 \\
\hline 550 & 0.43 & 0.30 & 0.13 & 0.30 \\
\hline 583 & 9.50 & 7.00 & 2.50 & 0.26 \\
\hline 654 & 2.73 & 1.64 & 1.08 & 0.39 \\
\hline 670 & 4.23 & 3.19 & 1.03 & 0.24 \\
\hline Mean & 3.53 & 1.95 & 1.58 & 0.48 \\
\hline SD & 2.53 & 2.06 & 0.94 & 0.19 \\
\hline$P^{*}$ & 0.41 & 0.027 & 0.017 & 0.00004 \\
\hline \multicolumn{5}{|c|}{$\begin{array}{l}\text { Heterozygotes } \\
\quad \text { (parents of } 488 \text { ) }\end{array}$} \\
\hline 394 & 1.49 & 0.34 & 1.15 & 0.77 \\
\hline 395 & 2.56 & 0.66 & 1.90 & 0.74 \\
\hline
\end{tabular}

Folate levels in fibroblast extracts were determined as described in Methods.

* Probability that mutants and controls are the same (Student $t$ test).

differential microbiological assay, and $x$, that calculated from column chromatography).

An attempt was made to determine if the distribution of nonmethylated folates observed in the cell extracts reflected the distribution of these within the cells before extraction. To determine if the $5-\mathrm{CHO}-\mathrm{H}_{4} \mathrm{PteGlu}$ found in the extracts could have come from 5,10$\mathrm{CH}=\mathrm{H}_{4} \mathrm{PteGlu}$, the latter was prepared by acid incubation (20) from commercial $5-\mathrm{CHO}-\mathrm{H}_{4} \mathrm{PteGlu}$ and purified by chromatography. This material, the identity of which was verified spectrophotometrically, was mixed with serum and treated exactly as was a cell extract. All of the $5,10-\mathrm{CH}=\mathrm{H}_{4} \mathrm{PteGlu}$ was converted to $10-\mathrm{CHO}-\mathrm{H}_{4}$ PteGlu, 10-CHO-PteGlu, and 5-CHO$\mathrm{H}_{4} \mathrm{PteGlu}$. The largest fraction formed was 5-CHO$\mathrm{H}_{4} \mathrm{PteGlu}$, suggesting that this material could have been formed from $5,10-\mathrm{CH}=\mathrm{H}_{4}$ PteGlu during extraction of folates. The quantity of $10-\mathrm{CHO}-\mathrm{H}_{4}$ PteGlu in the extracts could not be explained by such conversion.

To determine the proportion of intracellular folates which were present as short-chain and long-chain folates (poly- $\gamma$-glutamates), cell extracts were filtered 
through Sephadex G-25 and assayed for microbiological activity after deconjugation. The proportion of folate which was present in the excluded volume of the column and thus presumed to be polyglutamates (17) was not different in control and mutant cells (Table IV). The proportion of $5-\mathrm{CH}_{3}-\mathrm{H}_{4} \mathrm{PteGlu}$ within the polyglutamate fraction was decreased in mutant cells. This study indicates that the enzyme deficiency is reflected by a relative lack of $5-\mathrm{CH}_{3}-\mathrm{H}_{4} \mathrm{PteGlu}$ in the folate polyglutamate fraction and in the total folate of the cell.

The relationship between the proportion of cellular folate as 5- $\mathrm{CH}_{3}-\mathrm{H}_{4}$ PteGlu and the residual level of the mutant enzyme in the mutant cells is shown in Fig. 2. The residual level of enzyme was determined by comparing the mutant enzyme activity to the mean control level for the individual laboratory where the patient was studied. There was a direct relationship between the residual activity and the proportion of cellular folate as $5-\mathrm{CH}_{3}-\mathrm{H}_{4}$ PteGlu $(r=0.94, P=0.0001)$. When patients were ranked as to clinical severity (Table I) there was again a strong correlation between clinical findings and cellular $5-\mathrm{CH}_{3}-\mathrm{H}_{4}$ PteGlu fraction $(r=-0.95, P$ $=0.00005)$. When these were compared with the intracellular concentration of $5-\mathrm{CH}_{3}-\mathrm{H}_{4} \mathrm{PteGlu}$ rather than with the proportion of intracellular folate in this form, correlation was observed, but this was less than with the latter $(r=0.69$ and $0.71, P=0.029$ and 0.013 , respectively). A strong relationship was observed also between the proportion of intracellular folate which supported growth of $L$. casei in extracts, but did not support $P$. cerevisiae and both residual enzyme activity

TABLE IV

5-CH ${ }_{3}-\mathrm{H}_{4}$ PteGlu Distribution in Polyglutamyl Folates

\begin{tabular}{lcc}
\hline & $\begin{array}{c}\text { Fraction of total folate } \\
\text { which is polyglutamyl }\end{array}$ & $\begin{array}{c}\text { Fraction of polyglutamyl } \\
\text { folates which is 5-CH } \text { - }_{4} \text { PteGlu }\end{array}$ \\
\hline $\begin{array}{l}\text { Controls } \\
\text { Mean }\end{array}$ & 0.92 & \\
SD & 0.09 & $0.87^{*}$ \\
Mutants & & 0.04 \\
451 & 0.93 & \\
452 & 0.86 & 0.28 \\
488 & 0.78 & 0.41 \\
548 & 0.96 & 0.55 \\
654 & 0.93 & 0.29 \\
670 & 0.83 & 0.26 \\
Mean & 0.88 & 0.23 \\
SD & 0.07 & $0.35^{*}$ \\
\hline
\end{tabular}

Extracts of fibroblasts were filtered through Sephadex G-25 as described in Methods to distinguish short-chain folates from folate polyglutamates. The fraction of folate as $5-\mathrm{CH}_{3}-$ $\mathrm{H}_{4}$ PteGlu was determined as the differential activity between L. casei and P. cerevisiae.

* Means significantly different by Student $t$ test $(P \leq 0.003)$.

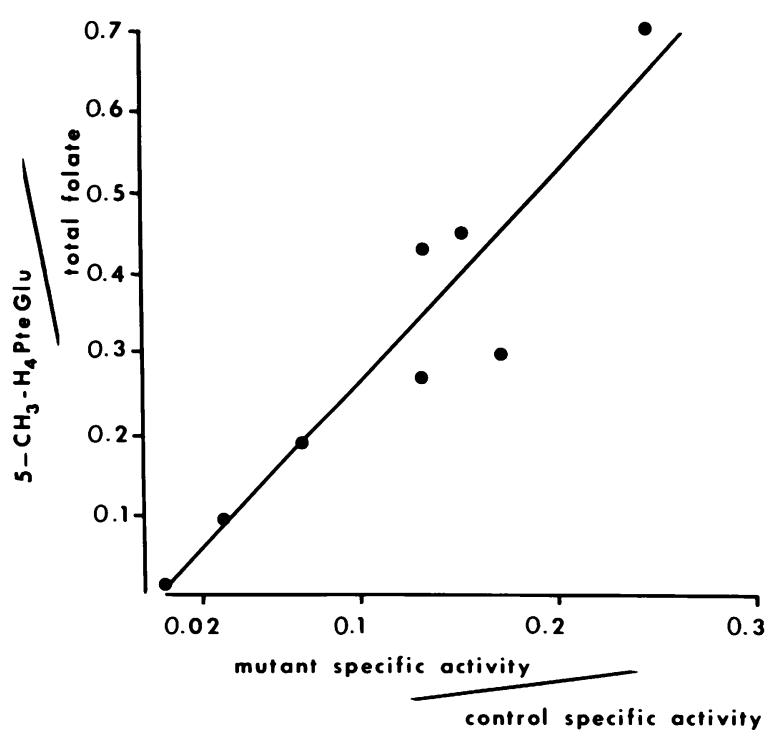

Figure 2 The proportion of total cellular folates as 5- $\mathrm{CH}_{3}$ $\mathrm{H}_{4} \mathrm{PteGlu}$ as a function of residual $5,10-\mathrm{CH}_{2}-\mathrm{H}_{4} \mathrm{PteGlu}$ reductase activity in deficient fibroblasts. The residual level of enzyme was determined by comparing published activities to the control values for the individual laboratory where the patient was studied. The proportion of $5-\mathrm{CH}_{3}-\mathrm{H}_{4} \mathrm{PteGlu}$ was determined from the DEAE chromatogram (Table II).

and clinical severity of the illness $(r=0.835$ and $-0.088, P=0.0025$ and 0.0008 , respectively).

\section{DISCUSSION}

These studies demonstrate the accumulation of polyglutamates of $5-\mathrm{CH}_{3}-\mathrm{H}_{4} \mathrm{PteGlu}$ as the major intracellular folate in fibroblasts grown in PteGlu, and the distribution of nonmethylated folates most of which were also in the polyglutamate form. The conditions of extraction and analysis of intracellular folate allowed chemical interconversion of some of these; indeed conversion of $5-10-\mathrm{CH}=\mathrm{H}_{4} \mathrm{PteGlu}$ to $10-\mathrm{CHO}-\mathrm{H}_{4} \mathrm{PteGlu}$, 10-CHO-PteGlu, and 5-CHO- $\mathrm{H}_{4}$ PteGlu was demonstrated during the procedure. The major folate fractions in the cell extracts after conversion of polyglutamate to monoglutamate folate were $5-\mathrm{CH}_{3}-\mathrm{H}_{4} \mathrm{PteGlu}$ and 10 CHO- ${ }_{4}$ PteGlu, and smaller quantities of 10-CHOPteGlu, $5-\mathrm{CH}_{3}-\mathrm{H}_{2} \mathrm{PteGlu}$, and $\mathrm{H}_{4} \mathrm{PteGlu}$ were also found. Of the last three, 10-CHO-PteGlu and $5-\mathrm{CH}_{3}-$ $\mathrm{H}_{2}$ PteGlu could have been formed during extraction and chromatography despite the presence of ascorbate and mercaptoethanol in the solutions, and much of the $\mathrm{H}_{4} \mathrm{PteGlu}$ could have been derived from $5-10-\mathrm{CH}_{2}-\mathrm{H}_{4}-$ PteGlu which would have been converted to $\mathrm{H}_{4} \mathrm{PteGlu}$ under the conditions of analysis. The data presented do, however, define the major intracellular folate as 5- $\mathrm{CH}_{3}-\mathrm{H}_{4} \mathrm{PteGlu}$, and $10-\mathrm{CHO}-\mathrm{H}_{4} \mathrm{PteGlu}$ as the major nonmethylated folate. 5-CHO- $\mathrm{H}_{4} \mathrm{PteGlu}$ may not be present within the unextracted cells. 
The mutant cells, deficient in $5,10-\mathrm{CH}_{2}-\mathrm{H}_{4}$ PteGlu reductase, contained the same intracellular concentration of folate, and the same group of folate coenzymes, although in all cases, the proportion of intracellular folate which was $5-\mathrm{CH}_{3}-\mathrm{H}_{4} \mathrm{PteGlu}$ folate was decreased below that of control cells. The deficiency of intracellular 5- $\mathrm{CH}_{3}-\mathrm{H}_{4}$ PteGlu in mutant cells was not surprising, because the deficient enzyme is considered the major pathway for formation of this folate. It was of interest to note that compensatory metabolic adjustments to correct this imbalance were not observed, and the only defect observed in growth was the previously described dependence of mutant cells on methionine as a growth factor not required by normal cells in the presence of homocysteine (5).

The patients from whom these fibroblasts were obtained had a variety of different clinical syndromes including psychological, neurological, and developmental abnormalities. Clinical ranking of the severity of their illness correlated very well with the residual enzyme activity and with the proportion of intracellular folate which was $5-\mathrm{CH}_{3}-\mathrm{H}_{4} \mathrm{PteGlu}$, and less well with the absolute concentration of this folate within the cultured cells. The absolute concentration of $5-\mathrm{CH}_{3}$ $\mathrm{H}_{4} \mathrm{PteGlu}$ was usually, but not always lower in mutant cells than in normal cells, suggesting that this intracellular concentration might not be the critical determinant of cellular metabolism. The close correlation of the proportion of intracellular folate which was $5-\mathrm{CH}_{3}$ $\mathrm{H}_{4}$ PteGlu with residual enzyme activity and clinical severity of disease suggests that the relative distribution of different folate coenzymes might be important in controlling folate-related metabolism. Such control might depend on competition by different folates for folate-dependent enzymes, so that excess or deficiency of one folate form might alter the availability of other folates for enzymes. Competition has been reported by 10-CHO- $\mathrm{H}_{4}$ PteGlu, $\mathrm{H}_{2}$ PteGlu, PteGlu, and $\mathrm{PteGlu}_{5}$ for human thymidylate synthetase with its natural coenzyme (21). The least-squares line comparing residual enzyme concentration with proportion of intracellular 5- $\mathrm{CH}_{3}-\mathrm{H}_{4} \mathrm{PteGlu}$ passed through the origin of the graph, indicating that the pathway uses the enzyme 5-10- $\mathrm{CH}_{2}-\mathrm{H}_{4} \mathrm{PteGlu}$ reductase is the only significant one for producing $5-\mathrm{CH}_{3}-\mathrm{H}_{4} \mathrm{PteGlu}$ in these cells, under these conditions of growth. The total intracellular folate of both mutant and normal cells was equal, indicating that failure to convert intracellular folate to $5-\mathrm{CH}_{3}-\mathrm{H}_{4}$ PteGlu does not affect folate accumulation by human fibroblasts in vitro. The intracellular folate concentration in human fibroblasts grown in PteGlu does not exceed that of the PteGlu in the culture medium (22).

Comparison of the proportion of intracellular folate which was $5-\mathrm{CH}_{3}-\mathrm{H}_{4} \mathrm{PteGlu}$, determined by chromatography with that by differential microbiological assay alone showed poor correlation, but that calculated by the latter was consistently higher when either S. fecalis or $P$. cerevisiae was compared with $L$. casei. This suggests that some of the nonmethyl folates were much more effectively used by L. casei for growth than by the two other test organisms. Differential microbiological assay alone on extracts of cultured fibroblasts however, does appear to be a good screening test for $5,10-\mathrm{Ch}_{2}-\mathrm{H}_{4}-$ PteGlu reductase deficiency.

\section{ACKNOWLEDGMENTS}

We gratefully acknowledge the expert technical assistance of Jack Hilton, Nora Vera Matiaszuk, and Angela Pottier. We thank Richard W. Erbe and Robert M. Hoffman for helpful advice in the initiation of these studies.

\section{REFERENCES}

1. Erbe, R. W. 1975. Inborn errors of folate metabolism. $N$. Engl. J. Med. 293: 753-758, 807-811.

2. Wong, P. W. K., P. Justice, M. Hruby, E. B. Weiss, and E. Diamond. 1977. Folic acid nonresponsive homocystinuria due to methylenetetrahydrofolate reductase deficiency. Pediatrics. 59: 749-756.

3. Wong, P. W. K., P. Justice, and S. Berlow. 1977. Detection of homozygotes and heterozygotes with methylenetetrahydrofolate reductase deficiency. J. Lab. Clin. Med. 90: 283-288.

4. Narisawa, K., Y. Wada, T. Saito, H. Suzuki, M. Kudo, T. Arakawa, N. Katsushima, and R. Tsuboi. 1977. Infantile type of homocystinuria with $\mathrm{N}^{5,10}$-methylenetetrahydrofolate reductase defect. Tohoku J. Exp. Med. 121: 185- 194.

5. Mudd, S. H., B. W. Uhlendorf, J. M. Freeman, J. D. Finkelstein, and V. E. Shih. 1972. Homocystinuria associated with decreased methylenetetrahydrofolate reductase activity. Biochem. Biophys. Res. Commun. 46: 905-911.

6. Freeman, J. M., J. D. Finkelstein, and S. H. Mudd. 1975. Folate-responsive homocystinuria and "schizophrenia". A defect in methylation due to deficient 5,10-methylenetetrahydrofolate reductase activity. N. Engl. J. Med. 292: 491-496.

7. Baumgartner, E. R., K. Schweizer, and H. Wick. 1977. Different congenital forms of defective remethylation in homocystinuria: clinical, biochemical and morphologic studies. Pediatr. Res. 11: 1015.

8. Kanwar, Y. S., J. R. Manaligod, and P. W. K. Wong. 1976. Morphologic studies in a patient with homocystinuria due to 5,10-methylenetetrahydrofolate reductase deficiency. Pediatr. Res. 10: 598-609.

9. Rosenblatt, D. S., and R. W. Erbe. 1977. Methylenetetrahydrofolate reductase in cultured human cells. II. Studies of methylenetetrahydrofolate reductase deficiency. Pediatr. Res. 11: 1141-1143.

10. Cooper, B. A., and D. Rosenblatt. 1976. Folate coenzyme forms in fibroblasts from patients deficient in 5,10-methylenetetrahydrofolate reductase. Biochemical Soc. Trans. 4: 921-922.

11. Schneider, E. L., E. J. Stanbridge, and C. J. Epstein. 1974. Incorporation of ${ }^{3} \mathrm{H}$-uridine and ${ }^{3} \mathrm{H}$-uracil into RNA. A simple technique for the detection of mycoplasma contamination of cultured cells. Exp. Cell. Res. 84: 311-318.

12. Rosenblatt, D. S., and R. W. Erbe. 1973. Reciprocal changes in the levels of functionally related folate en- 
zymes during the culture cycle in human fibroblasts. Biochem. Biophys. Res. Commun. 54: 1627-1633.

13. Rosenblatt, D. S., and R. W. Erbe. 1977. Methylenetetrahydrofolate reductase in cultured human cells. I. Growth and metabolic studies. Pediatr. Res. 11: 1137-1140.

14. Cooper, B. A., and E. Jonas. 1973. Superiority of simplified assay for folate with Lactobacillus casei ATCC 7469 over assay with chloramphenicol-adapted strain. J. Clin. $\mathrm{Pa}$ thol. (Lond.). 26: 963-967.

15. Lavoie, A., and B. A. Cooper. 1974. Rapid transfer of folic acid from blood to bile in man, and in conversion into folate coenzymes and into a peteroylglutamate with little biological activity. Clin. Sci. Mol. Med. 46: 729-741.

16. Nixon, P. F., and J. R. Bertino. 1971. Separation and identification of folate coenzymes on DEAE-Sephadex. Methods Enzymol. 18: 661-663.

17. Buehring, K. U., T. Tamura, and E. L. R. Stokstad. 1974. Folate coenzymes of Lactobacillus casei and Streptococcus fecales. J. Biol. Chem. 249: 1081-1089.

18. Cooper, B. A., and H. P. Girey. 1970. Studies of folic acid uptake by Lactobacillus casei. Biochim. Biophys. Acta. 208: 99-109.

19. Osborn, M. J., P. T. Talbert, and F. M. Huennekens, 1960. The structure of "active formaldehyde" $\left(\mathrm{N}^{5}, \mathrm{~N}^{10}\right.$-methylene tetrahydrofolic acid). Biochemistry. 82: 4921-4927.

20. Robinson, D. R. 1971. The non-enzymatic hydrolysis of $\mathrm{N}^{5} \mathrm{~N}^{10}$-methenyl-tetrahydrofolic acid and related reactions. Methods Enzymol. 18: 716-725.

21. Cheng, Y. C., D. W. Szeto, B. M. Dolnick, A. Rosowsky, C-S. Yu, E. J. Modest, J. R. Piper, C. Temple, Jr., R. D. Elliot, J. D. Rose, and J. A. Montgomery. 1979. Human thymidylate synthetase: action of folate and methotrexate analogs. In Chemistry and Biology of Pteridines. R. L. Kisliuk and G. M. Brown, editors. Elsevier North-Holland, Inc., New York, 377-381.

22. Hilton, J. G., B. A. Cooper, and D. S. Rosenblatt. 1979. Culture cycle dependence of folate distribution in human cells. In Chemistry and Biology of Pteridines. R. L. Kisliuk and G. M. Brown, editors. Elsevier North-Holland, Inc., New York. 303-308. 